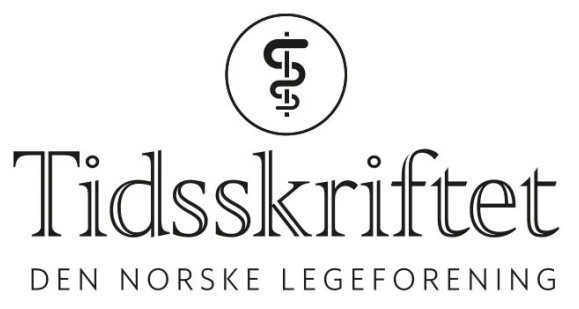

\title{
Smittevernlege: - Å beholde roen er det viktigste jeg har lært
}

REPORTASJE

\section{CAROLINE ULVIN JOHANSSON}

caroline.ulvin.johansson@tidsskriftet.no Tidsskriftet

Da den nye omikronvarianten eksploderte i Oslo, trykket assisterende bydelsoverlege Tine Ravlo på den røde knappen. Så fikk hun verdens øyne på seg. 


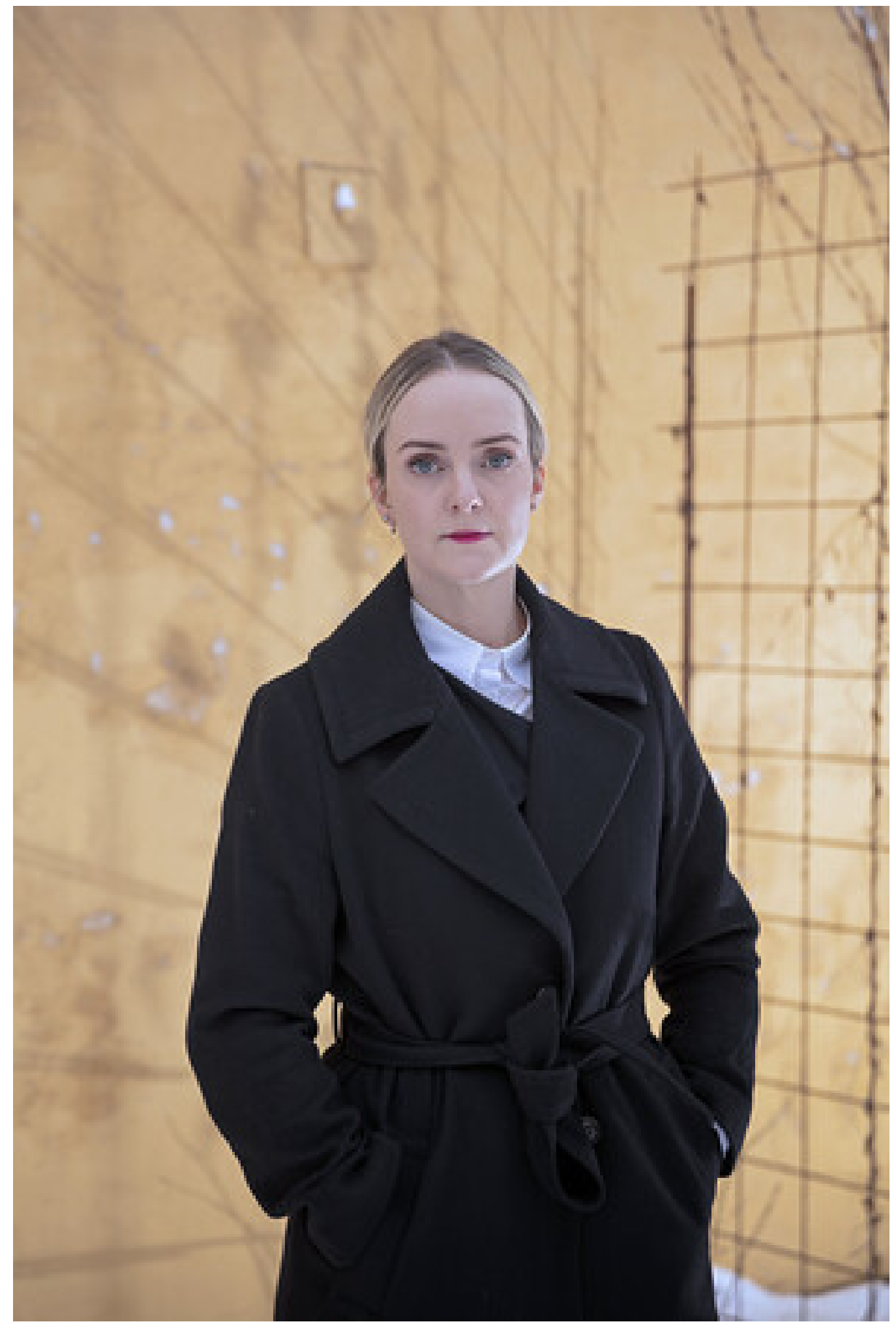

Assisterende bydelsoverlege i bydel Frogner, Tine Ravlo, har måttet håndtere et ras av henvendelser etter omikronutbruddet på Aker Brygge. Foto: Christian Tunge Pling! Svisj! Ring! Tine Ravlo (36) er overlegen som «alle» vil ha tak i for tiden. Telefonen hennes durer i ett sett, der hun sitter på hjemmekontoret på St. Hanshaugen i hovedstaden. Som assisterende bydelsoverlege i bydel Frogner i Oslo spiller hun en sentral rolle i smittesporingsarbeidet som foregår rundt det mye omtalte omikronutbruddet fra et julebord på Aker Brygge i slutten av november.

- Vi hørte om omikron i Sør-Afrika bare noen dager i forkant. Og plutselig fikk jeg en telefon fra Folkehelseinstituttet (FHI) om mulig funn av omikron på en PCR-prøve fra noen i min bydel. Da var det bare å trykke på den røde knappen med én gang, sier Ravlo. 
Det skulle vise seg at den aktuelle prøven tilhørte en person som hadde vært på et julebord med over 1oo deltakere på restauranten Louise. Situasjonen eskalerte raskt, og plutselig var Oslo senteret for det som muligens er et av de største kjente utbruddene av omikron i verden. I ettertid har dette medført et massivt smittesporingsarbeid og mediekjør for Ravlo og teamet hennes.

\section{Samtlige gjester og ansatte i karantene}

- Etter hvert som situasjonen utviklet seg, kom det inn flere og flere smittede. Da måtte vi iverksette enda flere tiltak, understreker den assisterende bydelsoverlegen.

Ring! Telefonskjermen lyser opp nok en gang, men Ravlo trykker resolutt på autobeskjeden "Jeg ringer deg tilbake», før hun fortsetter:

- Da det dukket opp enda flere tilfeller, så besluttet jeg at vi var nødt til å sette samtlige gjester og ansatte på Louise den kvelden i karantene. Det er veldig inngripende. Det innskrenker deres bevegelsesfrihet og har store negative konsekvenser for Louise, fordi det berører mange av deres ansatte.

$$
\begin{aligned}
& \text { «Vi jobber nå med å spore forgreninger som har skjedd før smitten ble } \\
& \text { oppdaget» }
\end{aligned}
$$

Hun presiserer at det var en utfordrende avveining å gjøre, ettersom omfanget var såpass stort. Men med både Folkehelseinstituttet, Helsedirektoratet og Oslo kommune i ryggen landet hun på at folkehelsen til syvende og sist måtte komme først - og fattet et hastevedtak etter smittevernloven.

Så langt har det aktuelle utbruddet ført til over 140 koronatilfeller, opplyser Ravlo. Per nå er det høyst sannsynlig at $60 \%$ av disse er smittet med omikronvarianten, og at det antagelig er flere.

- Vi jobber nå med å spore forgreninger som har skjedd før smitten ble oppdaget, sier hun.

Så langt har 17 personer fra det aktuelle julebordet fått bekreftet omikronsmitte, ifølge Folkehelseinstituttet, som også presiserer at de fleste deltakerne trolig har blitt smittet med denne varianten.

Instituttet opplyser på sine nettsider at det per 14. desember er innmeldt 1498 bekreftede omikrontilfeller på landsbasis. Fordelt på fylkene er det Oslo som har de høyeste tallene, med 691 tilfeller så langt (1).

- Vi forventer at antallet smittede med denne varianten vil øke raskt de nærmeste ukene. Dette, sammen med den allerede økte belastningen på helsetjenesten, gjør at vi nå vurderer situasjonen som alvorlig, opplyser kriseleder og avdelingsdirektør Line Vold i en pressemelding (므).

\section{Ville jobbe direkte med pandemien}

Fra hjemmekontoret leder Ravlo en gruppe smittesporere. De er en del av et smittesporingsteam på 40 årsverk som sitter intenst og jobber. 


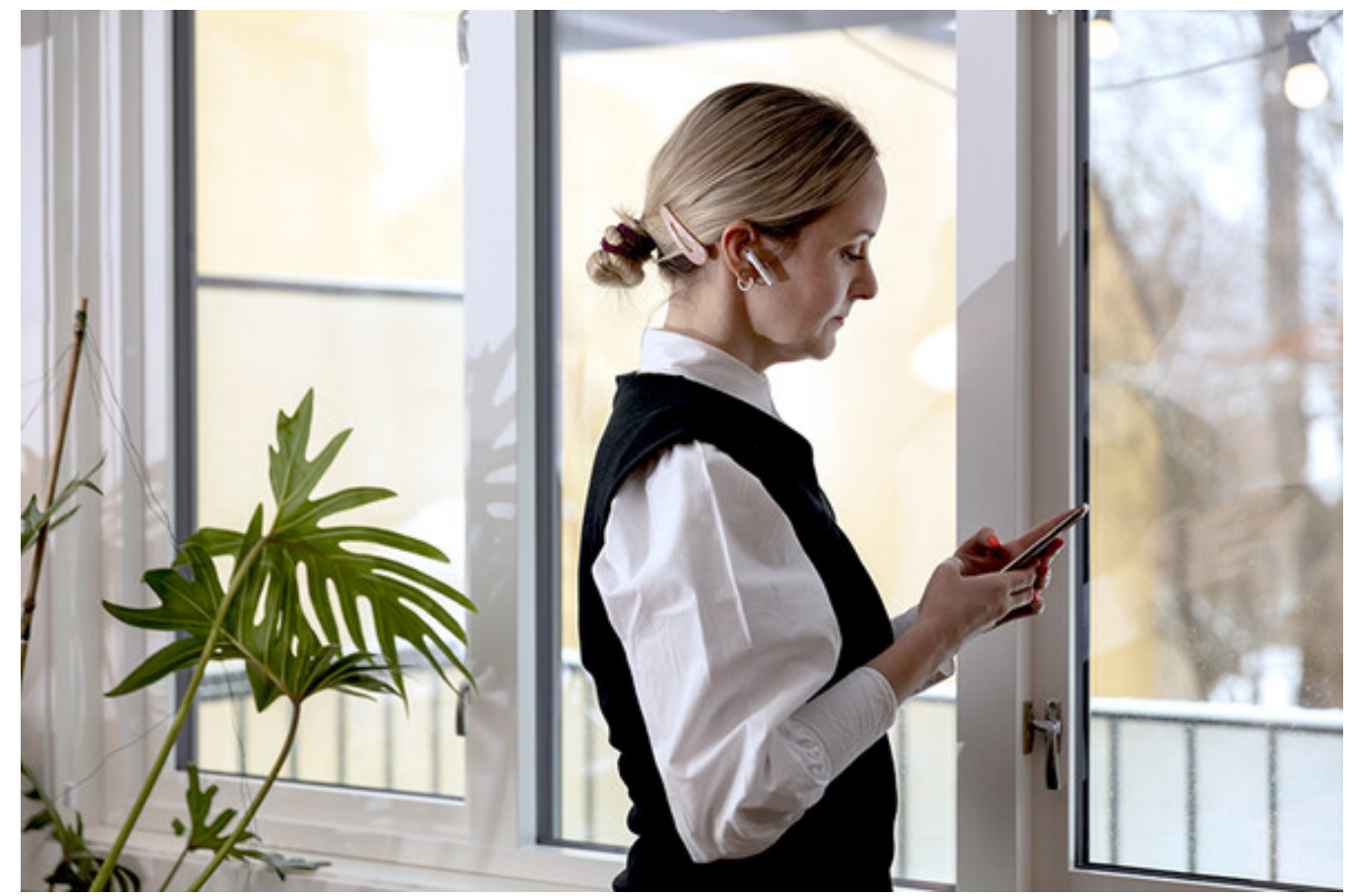

Tine Ravlo jobber lange dager fra hjemmekontoret på St. Hanshaugen. Foto: Christian Tunge

- Smitteteamet sparrer mot meg. Jeg beslutter, mens de iverksetter. Vi samarbeider tett og forsøker å få best mulig oversikt og kontroll raskest mulig.

Hun legger til at mye av smittesporingen er tillitsbasert og at de ikke kan kontrollere opplysningene.

- Det er jo detektivarbeid. Det er en slags etterforskning å finne ut av hvem folk har vært sammen med og få dem til å huske hvor de har vært og hva de har gjort.

Ravlo innrømmer at det har blitt mange 16-timersdager den siste tiden. Julepynten venter fremdeles på å bli hengt opp i vinduet, der snøen virvler forbi på utsiden. Men selv om stillingen som assisterende bydelsoverlege er krevende, angrer hun ikke på at hun takket ja til jobben for et år siden.

- Jeg søkte meg til denne stillingen på eget initiativ. Før jobbet jeg med andre ting, men hadde veldig lyst til å jobbe direkte med pandemien, forteller hun.

Ravlo har en variert yrkesbakgrunn å vise til. Hun ble ferdigutdannet i 2014 og hadde turnustjeneste på Bærum sykehus, før hun jobbet i kommunetjenesten på Lønnås legesenter. Hun har også jobbet på Gynekologisk poliklinikk ved Bærum sykehus, vært fastlegevikar og jobbet på helsestasjonen på Frogner. Men akkurat nå trives hun godt med pandemihåndtering.

- Det er jo dette det handler om i verden nå. Jeg føler meg veldig privilegert som har en meningsfull jobb. En veldig krevende jobb, men først og fremst meningsfull.

\section{Mangler kunnskap om vaksinebeskyttelse}

Den assisterende bydelsoverlegen presiserer at tilfellene tilknyttet julebordet så langt er relativt likt fordelt på kjønn og at de fleste er mellom 30 og 50 år. Symptomene som i størst grad går igjen, er hodepine, lav feber, hoste og tett nese. Enkelte beskriver også muskelverk, utmattelse og tap av lukte- og smakssans. Ingen har blitt alvorlig syke eller havnet på sykehus. Samtidig understreker overlegen at de smittede er voksne, friske og fullvaksinerte mennesker. 
- Vi har jo ikke sett hvordan omikronvarianten oppfører seg hos eldre, sårbare og alvorlig immunsupprimerte personer med underliggende sykdom. Vi vet at denne gruppen har fått tilbud om en tredje vaksinedose, men det er for tidlig å vite hvordan dette vil slå ut.

«Akkurat nå, mens dette store utbruddet pågår, er alle andre oppgaver på vent»

Hun får støtte av immunolog og seniorforsker ved Universitetet i Oslo og Oslo universitetssykehus Gunnveig Grødeland, som understreker at det nå er viktig å få vaksinert eldre og sårbare med en tredje vaksinedose:

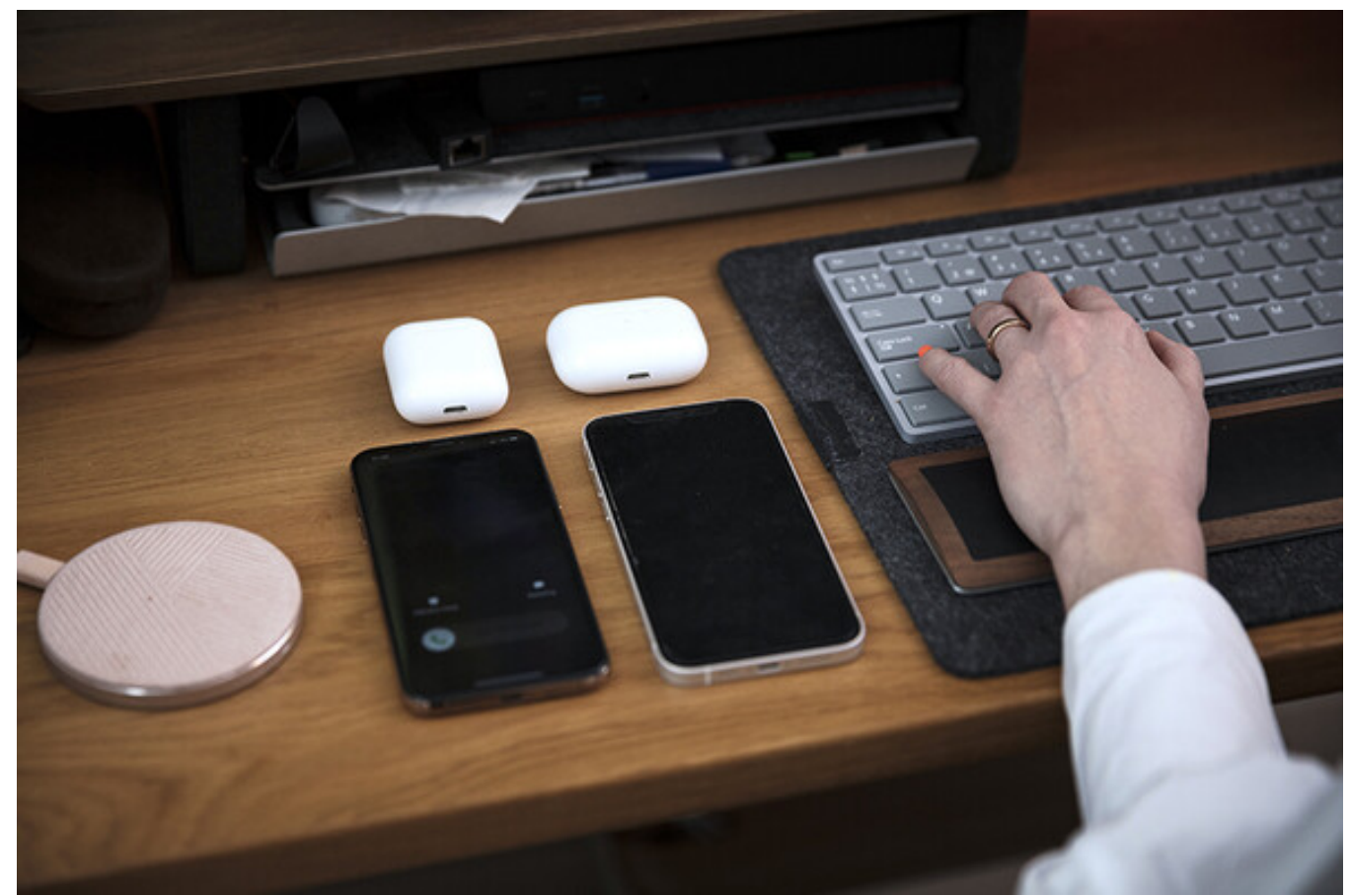

Smittesporingsarbeidet kan minne om detektivarbeid, ifølge Ravlo, som mottar en drøss av telefoner og henvendelser i forbindelse med omikronutbruddet. Foto: Christian Tunge - Det er tegn fra Sør-Afrika som tyder på at vi kan forvente god vaksinebeskyttelse mot alvorlig sykdom også for denne gruppen, men det er for tidlig å konkludere noe sikkert, forteller hun.

Grødeland legger til at et av de viktigste spørsmålene å få klarhet i akkurat nå er hvor godt vaksinene beskytter mot omikronvarianten.

- Vi vet at effekten som vaksinen har mot smitte, er redusert sammenlignet med mot deltavarianten.

Hun presiserer videre at dette er som forventet, fordi det første nivået av beskyttelse i stor grad skyldes nøytraliserende antistoffer som kan hindre viruset fra å trenge inn i cellene våre.

\section{Fakta om omikron}

Omikron er en mutert variant av koronaviruset SARS-CoV-2.

Varianten ble oppdaget i Sør-Afrika og meldt til Verdens helseorganisasjon 24. november.

26. november erklærte Verdens helseorganisasjon varianten som en bekymringsvariant, og den fikk betegnelsen omikron.

Varianten har hele ca. 50 mutasjoner i genomet, hvor 32 er i selve piggproteinet (spikeproteinet), som er den delen av viruset som vaksinene er basert på. 
- Når piggene (spike) på viruset endres, vil effekten av disse antistoffene gå ned. Når det er sagt, så danner jo vaksinene flere ulike lag av beskyttelse, og det ser så langt ut til at vi har god beskyttelse mot alvorlig sykdom også etter omikronsmitte.

\section{Vekker internasjonal oppsikt}

Etter at avisene fikk nyss om utbruddet på Aker Brygge, har Ravlo måttet håndtere et ras av henvendelser hun aldri før har opplevd. Til og med store, internasjonale medier som Wall Street Journal og New York Times har kontaktet eller sitert den assisterende bydelsoverlegen (3,4).

- Det er uvanlig for meg å få så mange henvendelser. Men jeg har tenkt at det er viktig å informere om det vi vet, forteller hun.

Og Ravlo har etter alt å dømme ikke mistet bakkekontakten av all oppmerksomheten.

- Det er ikke så annerledes om det er Aftenposten eller om det er Wall Street Journal som ringer meg. Begge har et behov for informasjon - noe jeg tenker det er viktig at de får, sier hun.

Den siste tiden har arbeidsdagen startet med å stå opp grytidlig, ta seg en dusj, få i seg kaffe, plassere seg foran PC-en og starte morgenmøtet - samtidig som hun håndterer en drøss av forskjellige henvendelser som plinger inn på telefon og e-post.

- Akkurat nå, mens dette store utbruddet pågår, er alle andre oppgaver på vent. Omikron er det eneste jeg fokuserer på, forteller Ravlo, og presiserer at hun vanligvis også har ansvar for blant annet LIS1-legene i bydelen og bistår bydelsoverlegen med LIS3-tjeneste for fastlegene, i tillegg til oppgaver knyttet til fastlegetjenesten. Ravlo er også medisinskfaglig ansvarlig for koronavaksinasjonen i bydelen og besvarer alle henvendelser knyttet til smittevern i tjenestene.

\section{Viktig å beholde roen}

Pling! Pling! Enda flere meldinger og ubesvarte anrop tikker inn på telefonen til den assisterende bydelsoverlegen, som snart må tilbake til smittesporing og detektivarbeid. Men Ravlo lar seg ikke stresse nevneverdig av alle som vil ha tak i henne. Hun fremholder at nettopp evnen til å holde hodet kaldt når det koker, er en viktig lærdom fra pandemien.

\section{«Nettopp evnen til å holde hodet kaldt når det koker, er en viktig lcerdom} fra pandemien"

- Man lærer jo noe hver eneste dag i denne jobben. Det er jeg takknemlig for. Det er et så meningsfylt og spennende arbeid. Men jeg tror det viktigste jeg har lært, handler om evnen til å beholde roen. Høye smittetall, store utbrudd, stengninger av skoler og andre store beslutninger som må tas - som har store, inngripende konsekvenser - kan være overveldende. Så da er det viktig å beholde roen.

- Er du bekymret for den fremtidige utviklingen?

- Det er klart at når jeg ser hvor smittsomt dette er, så er det bare snakk om tid før det er overalt, det er det ingen tvil om. Men spørsmålet er hvordan det påvirker sykdomsbyrden i samfunnet. 
1. Folkehelseinstituttet. Statistikk over meldte tilfeller av ny virusvariant (omikron). https://www.fhi.no/sv/smittsomme-sykdommer/corona/meldte-tilfeller-av-ny-virusvariant/ Lest 10.12.2021.

2. Folkehelseinstituttet. Alvorlig situasjon rundt omikronvarianten i Norge.

https://www.fhi.no/nyheter/2021/alvorlig-situasjon-rundt-omikronvarianten-i-norge/ Lest 10.12.2021.

3. Douglas J, Hinshaw D. Early lab test shows Omicron weakening vaccine effectiveness. Wall Street Journal 7.12.2021. https://www.wsj.com/articles/omicron-expected-to-be-dominant-strain-in-parts-ofeurope-within-weeks-11638889781 Lest 10.12.2021.

4. Erdbrink T, Libell HP, Frost N et al. A Christmas party in Norway becomes a possible Omicron spreading event, and other international news. New York Times 3.12.2021.

https://www.nytimes.com/2021/12/03/world/omicron-norway-christmas-party.html Lest 10.12.2021.

Publisert: 17. desember 2021. Tidsskr Nor Legeforen. DOI: 10.4045/tidsskr.21.0877

(C) Tidsskrift for Den norske legeforening 2023. Lastet ned fra tidsskriftet.no 26. april 2023. 